\title{
Knowledge, attitude, and practices about contraceptive in Western Rajasthan, India
}

\section{Gayatri Aseri*, Sudesh Agrawal}

Department of Obstetrics and Gynecology, SP Medical College Bikaner, Rajasthan, India

\author{
Received: 05 May 2018 \\ Revised: 28 May 2018 \\ Accepted: 30 May 2018 \\ *Correspondence: \\ Dr. Gayatri Aseri, \\ E-mail: gayatri.aseri@gmail.com
}

Copyright: $(\subset$ the author(s), publisher and licensee Medip Academy. This is an open-access article distributed under the terms of the Creative Commons Attribution Non-Commercial License, which permits unrestricted non-commercial use, distribution, and reproduction in any medium, provided the original work is properly cited.

\begin{abstract}
Background: This study was carried out to assess the knowledge, attitude, and practice of contraceptive methods among women attending a tertiary care hospital in Western Rajasthan.

Methods: This cross-sectional study was conducted in the department of obstetrics and gynecology, PBM and the associated group of hospitals, attached to Sardar Patel Medical College, Bikaner, Rajasthan, India. Total 500 married women between age group 15-49 yrs were included. These all women interviewed using a structured questionnaire after approval of the hospital's ethical committee.

Results: Total 500 women interviewed for their knowledge, attitude, and practices about contraception. Out of which, $402(80.4 \%)$ women had some knowledge of at least one contraception method at the time of the study. The most common sources of information about contraception were husband and family member. Amongst the various contraceptives most commonly known was condom (78.4\%). Only 265 (53\%) women were practicing contraception at present. Most commonly used contraceptive was condom (40.8\%). The most common reason for the non-practice of contraception was need of more child or male child in $34.8 \%$ families followed by opposition from in-laws $(12.4 \%)$.

Conclusions: Literacy was positively associated with family planning related knowledge and practices. Preconception knowledge and practices about contraception are poor in our study population. Many of the women were getting MTP pills over the counter without consulting to health care persons and then later presents with complications.
\end{abstract}

Keywords: Attitude, Contraceptive knowledge, Condoms, Family planning, Oral contraceptive pills, Practice

\section{INTRODUCTION}

Contraceptive advice is a component of good preventive health care. It is very much necessary to stabilize the population and to conserve the natural resources for future generations. An ideal contraceptive should suit an individual's personal, social, and medical characteristics and requirements. Socioeconomic factors, education are a few of the factors that play a vital role in family planning acceptance. ${ }^{1}$ To provide this, understanding the attitude and knowledge of the patient towards contraception is very much necessary. There are nearly 40 million women in India who would prefer to avoid becoming pregnant, but not practicing contraception. ${ }^{2}$

According to NFHS-3, about $30 \%$ of the fertility in India was unwanted, indicating a huge gap between the demand and supply of family planning and the unmet need the country as a whole is about $13 \%$ and this is high among married women aged 15-19 years (25\% for spacing and $2 \%$ for limiting) and among those aged 20 24 years (15\% for spacing and over $6 \%$ for limiting). ${ }^{3}$ 
Our country is the second most populous in the world, having a rapidly growing population, which is currently increasing at the rate of 16 million each year. To slow down this growth rate, the National Population Policy was revised by the Government of India in 2000, with the objective of bringing down the total fertility rate to the replacement level by 2010. Despite constant efforts by the government, unmet needs still remain. The reasons for these unmet needs have to be analyzed to the core for the better understanding of the situation and to help the government in the formulation of appropriate policies and modified approaches. ${ }^{4}$

Failure to prevent unintended pregnancies leads some women to terminate through induced abortion. In settings where abortion is restricted or illegal, mortality due to unsafe abortion practices can be substantial. Pregnancies that are insufficiently spaced apart have health consequences for both the mother and child. Birth intervals of less than 15 months have been shown to more than double the risk of maternal deaths. ${ }^{5}$

Despite constant efforts by the government, the unmet needs of contraception still remain. The reasons for these unmet needs have to be studied in detail for a better understanding of the situation and in the formulation of appropriate policies and approaches. ${ }^{3}$

This study was carried out to assess the knowledge, attitude, and practice of contraceptive methods among women attending a tertiary hospital. An effort was made to identify the reasons for not using contraceptive methods and thus know the reasons affecting the outcome of the family planning program in this part of western Rajasthan.

\section{METHODS}

This cross-sectional study was conducted in the department of obstetrics and gynecology, PBM and the Associated group of hospitals (tertiary care center), attached to Sardar Patel Medical College, Bikaner, Rajasthan, India after the approval of the hospital's ethics committee. Inclusion criterion - women of reproductive age group between 15-49 yrs came to the Obs. \& Gynae. Department, PBM Hospital during the study period (August 2015 to February 2017, total cases= 500). Postmenopausal women, women with the history of hysterectomy, severely ill and women not willing to participate were excluded.

\section{Initial assessment}

The questionnaire included

- Demographics of participants

- Knowledge about family planning

- Attitudes towards family planning method

- Practice of family planning

- Family planning service

\section{Demographics}

All the women included in the study were interviewed for their demographics and immigration information. It included information such as the participant's age, and level of education, marital status, and employment status.

\section{Knowledge}

Family planning knowledge consisted of knowledge of modern contraceptives and emergency contraceptives, source of information about family planning.

Table 1: Questionnaire regarding demodraphic informations.

\begin{tabular}{|l|l|}
\hline Age & $\begin{array}{l}\text { Age at the time of } \\
\text { marriage }\end{array}$ \\
\hline $1=14-19$ & $1=14-19$ \\
\hline $2=20-29 \mathrm{~s}$ & $2=20-29$ \\
\hline $3=30-39$ & $3=30-39$ \\
\hline $4=40-45$ & $4=40-45$ \\
\hline Level of education & $\begin{array}{l}\text { First conception after } \\
\text { marriage }\end{array}$ \\
\hline $1=$ Illiterate & $\begin{array}{l}1=5-10 \text { month of marriage } \\
\text { life }\end{array}$ \\
\hline $2=$ Can write and read & $\begin{array}{l}2=6-12 \text { month of marriage } \\
\text { life }\end{array}$ \\
\hline $3=1-8^{\text {th }}$ class & $3=1-5$ yr of marriage life \\
\hline $4=9$ th $-12^{\text {th }}$ class & $4=>5$ year of marriage life \\
\hline $5=$ Higher education & Religion \\
\hline Economic status & $1=$ Hindu \\
\hline $1=$ Poor $(<5000)$ & $2=$ Muslim \\
\hline $\begin{array}{l}2=\text { Middle class } \\
\text { (5000-15000) }\end{array}$ & \begin{tabular}{l}
$3=$ Christian \\
\hline $3=$ Upper $(>15000)$
\end{tabular} \\
\hline
\end{tabular}

\section{Attitude}

Attitude towards family formation consisted of the ideal age of having a first child, desired number of children, ideal birth spacing, and contraceptive uses. Attitudes toward family planning discussions included participant's attitude themselves, their husband's attitudes, their society's attitude from where they originate.

\section{Practice}

Practice of family planning included age of getting married, after marriage use of any contraceptives, planned pregnancy, birth spacing, and history of requesting abortion, cause of induced abortion, desire for more children, use any contraceptives now, which method of contraceptives were being used and causes of not using any contraceptives. Usage of contraception refers to the use of contraceptives by at least one method, either traditional or modern method such as pills, 
Injection, IUD, condom, male or female sterilization, diaphragm, or withdrawal and abstinence. Traditional method refers to natural methods, including withdrawal and abstinence. A modern method refers to artificial methods that include injection, IUD, condom, male or female sterilization, and diaphragm.

Table 2: Questionnaire regarding knowledge about contraceptives.

\begin{tabular}{|ll|}
\hline $\begin{array}{l}\text { Knowledge about types of } \\
\text { contraceptives }\end{array}$ & $\begin{array}{l}\text { Source of information } \\
\text { about types of } \\
\text { contraceptives }\end{array}$ \\
\hline a) Natural calendar method & a) Family member \\
\hline b) Withdrawal method & b) Friends \\
\hline c) Condom & c) Health worker \\
\hline d) Oral pills & d) School teacher \\
\hline e) Injectable & e) Printed media \\
\hline f) IUCD & g) Audiovisual media \\
\hline $\begin{array}{l}\text { g) Emergency } \\
\text { contraception }\end{array}$ & h) Other.......... \\
\hline h) Female sterilization & \\
\hline i) Male sterilization & \\
\hline j) Medical abortion & \\
\hline k) Lactational amenorrhea & \\
\hline l) None & \\
\hline
\end{tabular}

Table 3: Questionnaire regarding attitude towards family formation.

\begin{tabular}{|ll|}
\hline $\begin{array}{l}\text { First conception after } \\
\text { marriage }\end{array}$ & $\begin{array}{l}\text { Duration between first } \\
\text { child birth and second } \\
\text { conception }\end{array}$ \\
\hline $1=1-5$ month of marriage life & $1=<6$ month \\
\hline $\begin{array}{l}2=6-12 \text { month of marriage } \\
\text { life }\end{array}$ & $2=6-12$ month \\
\hline $3=1-5$ yr of marriage life & $3=1-2$ years \\
\hline $0=>5$ yr of marriage life & $4=2-5$ years \\
\hline
\end{tabular}

Table 4: Questionnaire regarding current practices of contraceptives.

\begin{tabular}{|ll|}
\hline $\begin{array}{l}\text { Which method is } \\
\text { currently using }\end{array}$ & $\begin{array}{l}\text { Reason for not using any } \\
\text { contraceptives }\end{array}$ \\
\hline $\begin{array}{l}\text { a) Natural calendar } \\
\text { method }\end{array}$ & $\begin{array}{l}\text { a) Because at first day of } \\
\text { my marriage everybody } \\
\text { give me blessing that } \\
\text { "dudho Naho photo folio “ }\end{array}$ \\
\hline b) Withdrawal method & b) Need child \\
\hline c) Condom & c) Opposition from in laws \\
\hline d) Oral pills & $\begin{array}{l}\text { d) d/t undesirable side } \\
\text { effects }\end{array}$ \\
\hline e) Injectable & e) Inconvenience for use \\
\hline f) IUCD & f) Unsustained available \\
\hline $\begin{array}{l}\text { g) Emergency } \\
\text { contraception }\end{array}$ & g) Need not felt \\
\hline h) Female sterilization & h) Too young to use \\
\hline i) Male sterilization & i) Never thought about it \\
\hline
\end{tabular}

\section{Statistical analysis}

The data were entered in Microsoft excel spreadsheet. Descriptive statistics, i.e. mean, median and standard deviation (SD) for continuous variables and frequency distribution and their percentage for categorical variables were calculated.

\section{RESULTS}

Total 500 women interviewed during study period (demographic details in Table 5) out of which 402 $(80.4 \%)$ were aware of at least one contraceptive method. But none of them had the high level of knowledge of different contraceptive methods.

Table 5: Demographic details.

\begin{tabular}{|lll|}
\hline Characteristics & Number & Percentage \\
\hline Age in yrs & \multicolumn{2}{l|}{} \\
\hline$<20$ & 97 & 19.40 \\
\hline 21 -30 & 325 & 65 \\
\hline $31-40$ & 43 & 8.60 \\
\hline$>40$ & 35 & 7 \\
\hline Religion & & \\
\hline Hindu & 418 & 83.6 \\
\hline Muslim & 82 & 16.4 \\
\hline Education (women) & & \\
\hline Illiterate & 246 & 49.2 \\
\hline Can read \& write & 14 & 2.8 \\
\hline Class 1-8 & 161 & 32.2 \\
\hline Class 9-12 & 61 & 12.2 \\
\hline Higher education & 18 & 3.6 \\
\hline Occupation (women) & & \\
\hline Housewife & 441 & 88.2 \\
\hline Agriculture & 11 & 2.2 \\
\hline Govt job & 46 & 9.2 \\
\hline Pvt job & 2 & 0.4 \\
\hline Education (husband) & & \\
\hline Illiterate & 120 & 24 \\
\hline Can read \& write & 20 & 4 \\
\hline Class 1-8 & 160 & 32 \\
\hline Class 9-12 & 112 & 22.4 \\
\hline Higher education & 88 & 17.6 \\
\hline Occupation (husband) & & \\
\hline Agriculture & 77 & 15.4 \\
\hline Govt & 78 & 15.6 \\
\hline Private & 275 & 55 \\
\hline Other & 10 \\
\hline Family economic status (per month) & \\
\hline Poor (<5000) & 233 & 46.6 \\
\hline Middle (5000-15000) & 235 \\
\hline Upper (>15000) & \\
\hline
\end{tabular}


Table 6: Knowledge, attitude, and practice about various contraceptives.

\begin{tabular}{|c|c|c|}
\hline & No. & Percentage \\
\hline \multicolumn{3}{|l|}{ Source of information } \\
\hline Husband and family member & 276 & 55.2 \\
\hline Friends & 158 & 19.75 \\
\hline Health worker & 118 & 14.75 \\
\hline School teacher & 4 & 0.8 \\
\hline Printed media & 129 & 25.8 \\
\hline Audiovisual & 232 & 46.4 \\
\hline \multicolumn{3}{|c|}{ Knowledge about types of contraceptives* } \\
\hline Natural calender & 27 & 5.4 \\
\hline Withdrawal method & 134 & 26.8 \\
\hline Condom & 392 & 78.4 \\
\hline Oral contraceptive pills & 333 & 66.6 \\
\hline Injectables & 101 & 20.2 \\
\hline IUCD & 307 & 61.4 \\
\hline Emergency contraception & 264 & 52.8 \\
\hline Female sterilisation & 350 & 70 \\
\hline Male sterilisation & 193 & 38.6 \\
\hline Lactational & 26 & 3.25 \\
\hline Others** & 8 & 1.6 \\
\hline \multicolumn{3}{|l|}{ Types of contraception used } \\
\hline Natural calender & 2 & 0.4 \\
\hline Withdrawal method & 10 & 2 \\
\hline Condom & 204 & 40.8 \\
\hline Oral contraceptive pills & 85 & 17 \\
\hline Injectables & 10 & 2 \\
\hline IUCD & 80 & 16 \\
\hline Emergency contraception & 9 & 1.8 \\
\hline Female sterilisation & 75 & 15 \\
\hline Male sterilisation & 10 & 2 \\
\hline Lactational & 2 & 0.4 \\
\hline \multicolumn{3}{|c|}{ Reasons for not using contraception } \\
\hline $\begin{array}{l}\text { Because at first day of my } \\
\text { marriage everybody give me } \\
\text { blessing that "dudho naho puto } \\
\text { falo " }\end{array}$ & 4 & 0.8 \\
\hline Need child and male child & 174 & 34.8 \\
\hline Opposition from in-laws & 62 & 12.4 \\
\hline Due to undesirable side effects & 11 & 2.2 \\
\hline Inconvenience for use & 26 & 5.2 \\
\hline Unsustained availability & 37 & 7.4 \\
\hline Need not felt & 16 & 3.2 \\
\hline Too young for use & 9 & 1.8 \\
\hline Never thought about it & 2 & 0.4 \\
\hline
\end{tabular}

They had multiple sources of information amongst them most common was husband and family member 276 (55.2\%), followed by friends 158 (19.75\%). Health worker and the school teachers were least common 118 $(14.75 \%)$ and $4(0.8 \%)$ respectively. Amongst all known contraceptives condom and female sterilisation were the most known methods $78.4 \%$ and $70 \%$ respectively (Table $6)$.

Table 7: Relation between knowledge and practice with literacy.

\begin{tabular}{|llll|}
$\begin{array}{l}\text { Education } \\
\text { status of } \\
\text { women }\end{array}$ & $\begin{array}{l}\text { Total } \\
\text { no. of } \\
\text { women }\end{array}$ & $\begin{array}{l}\text { women had } \\
\text { some } \\
\text { knowledge } \\
\text { about } \\
\text { contraception }\end{array}$ & $\begin{array}{l}\text { Women who } \\
\text { use } \\
\text { contraception }\end{array}$ \\
\hline $\begin{array}{llll}\text { Illiterate } \\
\text { Can read \& } \\
\text { Write }\end{array}$ & 246 & $176(71.54 \%)$ & $134(54.47 \%)$ \\
\hline $\begin{array}{l}\text { Class 1-8 } \\
\text { Class 9-12 }\end{array}$ & 161 & $12(85.71 \%)$ & $8(57.14 \%)$ \\
\hline $\begin{array}{l}\text { Higher } \\
\text { education }\end{array}$ & 18 & $18(88.2 \%)$ & $72(44.72 \%)$ \\
\hline Total & 500 & 402 & $41(67.21 \%)$ \\
\hline
\end{tabular}

Out of $402(80.4 \%)$ women who had knowledge of contraception, only $265 \quad(53 \%)$ was practicing contraception at present. Most commonly used contraceptive was condom $204(40.8 \%)$ followed by OCP $85(17 \%)$ and IUCD $80(16 \%)$. The most common reason for the nonpractice of contraception was need of more child $174(34.8 \%)$ followed by opposition from in-laws in $62(12.4 \%)$ (Table 6).

Illiteracy was positively associated with family planning related knowledge and practices. Conversely, the women with higher education had knowledge but only half of them were practicing contraceptives (Table 7).

Table 8: Duration of marriage and first conception.

\begin{tabular}{|lll|}
\hline $\begin{array}{l}\text { Duration between } \\
\text { marriage and first } \\
\text { conception }\end{array}$ & $\begin{array}{l}\text { No of } \\
\text { patients }\end{array}$ & Percentage \\
\hline $1-6$ months & 147 & 29.4 \\
\hline $6-12$ months & 158 & 31.6 \\
\hline $1-5$ years & 183 & 36.6 \\
\hline$>5$ years & 2 & 0.4 \\
\hline
\end{tabular}

Almost $60 \%$ of women conceived within 1 year of marriage and around half of the women (48.2\%) again conceived within 2 years of first childbirth (Table 8 and 9).

Table 9: Duration between first childbirth and second conception.

\begin{tabular}{|lll|}
\hline $\begin{array}{l}\text { Duration between second } \\
\text { conception and first } \\
\text { childbirth }\end{array}$ & No. & Percentage \\
\hline <6 months & 11 & 2.2 \\
\hline 6-12 months & 56 & 11.2 \\
\hline $1-2$ years & 174 & 34.8 \\
\hline 2-5 years & 96 & 19.2 \\
\hline
\end{tabular}


Table 10: Source of information and availability about MTP pills/emergency pills.

\begin{tabular}{|lll|}
\begin{tabular}{|l} 
Source of \\
information
\end{tabular} & No & Percentage \\
\hline $\begin{array}{l}\text { Source of information about emergency /MTP } \\
\text { contraceptives }\end{array}$ & \\
\hline Friends & 234 & 46.8 \\
\hline Family members & 240 & 48 \\
\hline Media & 20 & 4 \\
\hline Magazine & 3 & 0.6 \\
\hline Internet & 20 & 4 \\
\hline Health facilities & 10 & 2 \\
\hline $\begin{array}{l}\text { Information about available source from where } \\
\text { they can get MTP pills }\end{array}$ \\
\hline Hospital & 47 & 9.4 \\
\hline Health worker & 10 & 2 \\
\hline Private clinic & 170 & 34 \\
\hline Pharmacy & 184 & 36.8 \\
\hline
\end{tabular}

Out of 500 women, $264(52.8 \%)$ women heard about MTP/emergency pills at some point in time. The most common sources of information were family members (48\%) and friends (46.8\%). Most common known available source to get the MTP pills if needed was pharmacy $184(36.8 \%)$ followed by private clinic 170 (34\%) and government hospitals $47(9.4 \%)$ and only 10 (2\%) women told that they will get it from health workers (Table 10). 64 had a previous history of abortion including 8 women with the history of multiple abortions. Out of these 64 women who had a previous history of abortion, 36 women took MTP pills. These women had multiple sources of information. The most common source was family members $34(6.8 \%)$ followed by friends $30(6 \%)$. Less common sources of information were media $1(0.2 \%)$, magazine $1(0.2 \%)$, internet 1 $(0.2 \%)$ and none from health facilities. Women who took MTP pills, the husband were the most common provider of MTP pills.

\section{DISCUSSION}

This study was designed to understand the knowledge and practices of women regarding family planning methods in western Rajasthan of India. We found that the illiteracy of the female was much more common in our study population compared to other population studied in different parts of India. Out of 500 studied women, almost half of the women and their in-laws were illiterate. Though the literacy rate was more in men, still $24 \%$ men were also illiterate.

Although 402 (80.4\%) women had some knowledge of contraceptive method at the time of the study but none had a good level of knowledge of different contraceptive methods. Similar results were seen in the study conducted by Pegu et al. ${ }^{6}$ Amongst multiple contraceptives most known contraceptive method was condom (78.4\%) followed by female sterilization (70\%). These results differed from the studies of Reena et al and Mao et al were the most known method of contraception was the intrauterine contraceptive device (IUCD) $(61.2 \%)$ and female sterilization respectively. ${ }^{4,7}$

The most common sources of information about contraception were husband and family member followed by audiovisual media. The least common source was information obtained from a health worker $118(14.75 \%)$ and from school teachers $4(0.8 \%)$. A study was done by Sharma et al also shows social circle and friends as the most frequent source of information. ${ }^{8}$ Contradicting the study of Pegu et al in which information was mainly obtained from health workers $(58.6 \%)$ followed by media $(24.1 \%)$ and social circle $(15.5 \%){ }^{6}$

Even though the $402(80.4 \%)$ women were aware of contraception, only 265 (53\%) women were using it at the time of the study. The most commonly used contraceptive method was condom $(40.8 \%)$ followed by OCPs (17\%), IUCD (16\%) and female sterilization $(15 \%)$. Similar results were seen in the study of Pegu et al. ${ }^{6}$ The need for more children or male child was the most common reason for the non-practice of contraception followed by opposition from in-laws. But in the study of Sharma et al (2005) fear of side effects was the most common reason for non practice. ${ }^{8}$

Still, 64 (12.8\%) women delivered at home, suggestive of poor health facilities available in the rural areas of the study population. Almost half of women conceived in less than 2 years of their first childbirth. The study of Agarwal et al also shown that, in general, women who desire another child, do not want to conceive for at least 18 months after their last birth. ${ }^{9}$ However, this desire to delay pregnancy often does not translate into the use of contraceptives.

Around 52.8\% women heard about MTP/emergency pills at some point in time. The most common sources of information were family members $(48 \%)$ and friends $(46.8 \%)$. The information regarding source to get MTP pills if needed $36.8 \%$ women told they will get it from the pharmacy, followed by private clinics $(34 \%)$, government hospitals $(9.4 \%)$ and only $2 \%$ women told that they will get it from health workers. Total 64 women had a history of abortion, including 8 women with a history of multiple abortions. Out of these 64 women, 36 women took MTP pills. In most of the cases, MTP pills were provided by the husband and family members. The usage of firsttrimester termination methods of medication over the counter is quite prevalent in these women. They don't seek advice from qualified personnel before consuming medication but present with after effects and complications like incomplete abortion, retained products of conception, anemia to the tertiary care centers. Out of these 36 women who took MTP pills, 15 came into our hospital with complications. Similar results were seen in the study of Harshini et al. ${ }^{10}$ 


\section{CONCLUSION}

Practicing family planning and to choose the correct contraceptives is very much essential. Literacy was positively associated with family planning related knowledge and practices. Preconception knowledge and practices about contraception are poor in our study population. Even though the knowledge about contraception improved after first childbirth, many women still not were practicing it. Other than social factors, illiteracy and lack of sex education may be the reason for poor knowledge about contraception. Husband and family members were the most common source of information about the contraception. Condom, Oral contraceptive pills, male and female sterilisation were the common practicing methods of contraception. Many of the women were getting MTP pills over the counter without consulting to health care persons and then later presents with complications.

Funding: No funding sources

Conflict of interest: None declared

Ethical approval: The study was approved by the Institutional Ethics Committee

\section{REFERENCES}

1. Mahawar P, Anand S, Raghunath D, Dixit S. Contraceptive knowledge, attitude and practices in mothers of infant: a cross-sectional study. National $\mathbf{J}$ Comm Med. 2011;2(1):105-7.

2. Park JE. Park's Textbook of Preventive \& Social Medicine. 20th edition. 2009 ; 421

3. Sunita TH, Rathnamala M Desai. Knowledge, attitude and practice of contraception among women attending a tertiary care hospital in India. Int $\mathbf{J}$ Reprod Contracept Obstet Gynecol. 2013;2(2):172-6.

4. Reena S, Kumar SD, Radha J, Kumkum S, Neela S, Sushmita S. Contraceptive knowledge attitude and practice (KAP) survey. JOGI. 2005;55(6):546-50.

5. World Bank and Save the Children. Essential Newborn Care. Washington DC: World Bank. 2004.

6. Pegu B, Gaur BPS, Sharma N, Singh ASS. Knowledge, attitude and practices of contraception among married women. Int $\mathrm{J}$ Reprod Contracept Obstet Gynecol. 2014;3(2):385-8.

7. Mao J. Knowledge, Attitude and Practices of Family Planning: A study of Tezu Village, Manipur (India). Internet J Biol Anthropol. 2006;1(1)

8. Sharma J, Dorairajan G, Chinnakali P. Knowledge and attitude towards contraceptive methods for spacing and decision making factors regarding its use in postpartum women. Int $\mathrm{J}$ Reprod Contracept Obstet Gynecol. 2015;4(3):750-4.

9. Agarwal N, Gupta M, Sharma A, Arora R. Antenatal counselling as a tool to increase acceptability of postpartum intrauterine contraceptive device insertion in a tertiary care hospital. Int $\mathbf{J}$ Reprod Contracept Obstet Gynecol. 2015;4(4):1137-41.

10. Nataraja HG, Harshini V. Contraceptive Knowledge Attitude and Practice (KAP) among Women who were seeking for Termination of Pregnancy. Asian J Biomed Pharmaceutic Sci. 2013;3(23):4-6.

Cite this article as: Aseri G, Agrawal S. Knowledge, attitude, and practices about contraceptive in Western Rajasthan, India. Int J Reprod Contracept Obstet Gynecol 2018;7:2786-91. 